\title{
Kilka uwag na temat pierwszego sezonu badawczego w Soba (Sudan)
}

\author{
Some Remarks on the First Research Season in Soba (Sudan)
}

Dla Sudańczyków termin Soba ma dzisiaj zasadniczo dwa znaczenia. Po pierwsze oznacza niegdysiejszą stolicę średniowiecznego, nubijskiego królestwa - Alodii („Soba miniona”); po drugie jest to nazwa żywiołowo rozwijającej się strefy podmiejskiej aglomeracji chartumskiej („Soba współczesna”). Te dwie nachodzące na siebie nieustająco czasoprzestrzenie stały się głównym przedmiotem badań etnograficznych (listopad-grudzień 2019 roku). Impulsem do ich podjęcia był pierwszy sezon wykopaliskowy badaczy z Centrum Archeologii Śródziemnomorskiej Uniwersytetu Warszawskiego na stanowisku Soba (fot. 1). Badania archeologiczne w Soba są realizowane z przerwami od początku XX wieku przez liczne grono archeologów (E.A.W. Budge, S. Clarke, P.L. Shinnie, D.A. Welsby i C.M. Daniels). W tym sensie projekt „Soba - serce królestwa Alwy”1, którego kierownikiem jest doktor Mariusz Drzewiecki z Centrum Archeologii Śródziemnomorskiej Uniwersytetu Warszawskiego, wpisuje się w długą tradycję badań archeologicznych na tym stanowisku - co warto podkreślić, jednym z najważniejszych dla archeologii Sudanu. W przeciwieństwie jednak do dotychczasowych prac, uwaga badaczy skupia się teraz na organizacji przestrzennej dawnej stolicy - jak mogła ona wyglądać oraz jak funkcjonowała w najszerszym możliwym do określenia przestrzennym wymiarze. Pewnego rodzaju novum są także badania etnograficzne, prowadzone przez etnologa, a stanowiące integralną i równorzędną część prowadzonych w terenie prac.

1 Projekt finansowany przez Narodowe Centrum Nauki na podstawie umowy nr UMO-2018/29/B/HS3/02533. 
Miejsce to nigdy nie było obiektem tego typu badań. Poszerzenie eksploracji archeologicznych o kontekst etnograficzny jest tym bardziej uzasadnione, iż aktualnie stanowisko archeologiczne stało się częścią wiejsko-miejskiej zabudowy, położonej

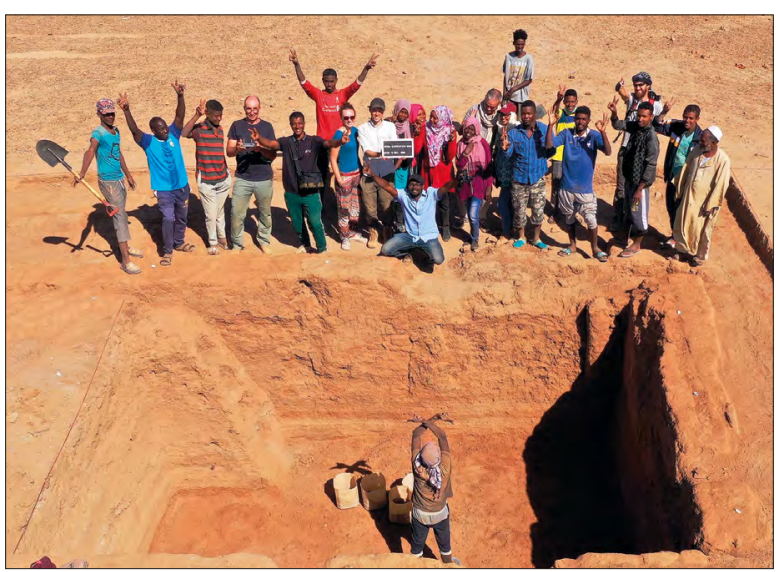

Fot. 1 Uczestnicy pierwszego sezonu wykopaliskowego, Soba (2019)

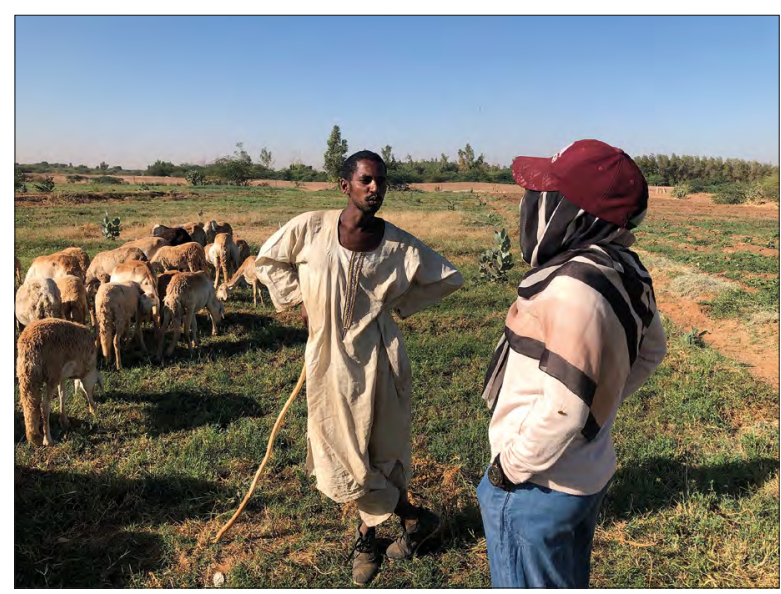

Fot. 2 W czasie jednego z wywiadów z pasterzem wypasającym owce na stanowisku archeologicznym, Soba (2019) zaledwie kilka kilometrów od chartumskiej metropolii. W niniejszym tekście podejmuję się zaprezentowania pierwszych wyników badań etnograficznych w Soba, realizowanych we współpracy z polskimi i sudańskimi archeologami.

W badaniach interesowało mnie, jak kształtują się relacje między ludźmi a śladami archeologicznymi - szerzej - stanowiskiem archeologicznym, oraz również to, czy i w jakim zakresie starożytna Soba jest częścią lokalnej historii. Podejmowane były także kwestie wytwarzania przestrzeni społecznej, a tym samym reprodukcji grupy, w tym jej pamięci historycznej, a także sposoby zakorzenienia oraz nadawania miejscu znaczenia.

W badaniach etnograficznych przyjąłem następujące hipotezy. (1.) Pamięć historyczna mieszkańców nie jest nazbyt długa. (2.) Permanentna kohabitacja ze śladami archeologicznymi musiała wśród nich ukształtować jakiś stosunek do zabytków. (3.) "Soba miniona” jest identyfikacyjną czasoprzestrzenią, w której materializuje się historia oraz pamięć (Appadurai 1995). (4.) Wykopaliska wiążą się ze zmianą kulturową. (5.) Ważną kwestią jest też w końcu współpraca z lokalną społecznością. Trzeba uświadamiać mieszkańców, jak wyglądają archeologiczne prace, z czym się wiążą, jakie mogą być ich pozytywne konsekwencje.

Badania etnograficzne, prowadzone za pomocą wywiadów i obserwacji, realizowane były w Soba-Gana’ab - regionie mieszkalnym przylegającym bezpośrednio 
do stanowiska archeologicznego. W badaniach wzięli udział, w charakterze asystentów, studenci Uniwersytetu Al-Neelain oraz stażyści sudańskiej służby starożytności (NCAM) - przede wszystkim Raja el Amean (fot. 2). W prace zaangażowany był także Al Montasir Dafalla Mohamed Elamin Elmoubark, pracownik NCAM, zarazem doktorant na Uniwersytecie im. Adama Mickiewicza w Poznaniu.

\section{„Soba miniona” versus „Soba współczesna”}

W średniowieczu Soba była stolicą jednego z najbardziej wysuniętych na południe królestw nubijskich - Alodii². Jej pozostałości znajdują się na prawym (wschodnim) brzegu Nilu Błękitnego, zaledwie kilkanaście kilometrów od Chartumu (Chartum Północny). Soba, założona prawdopodobnie na przełomie V i VI wieku, była rozległym i ludnym miastem z licznymi kościołami, klasztorami, ogrodami,

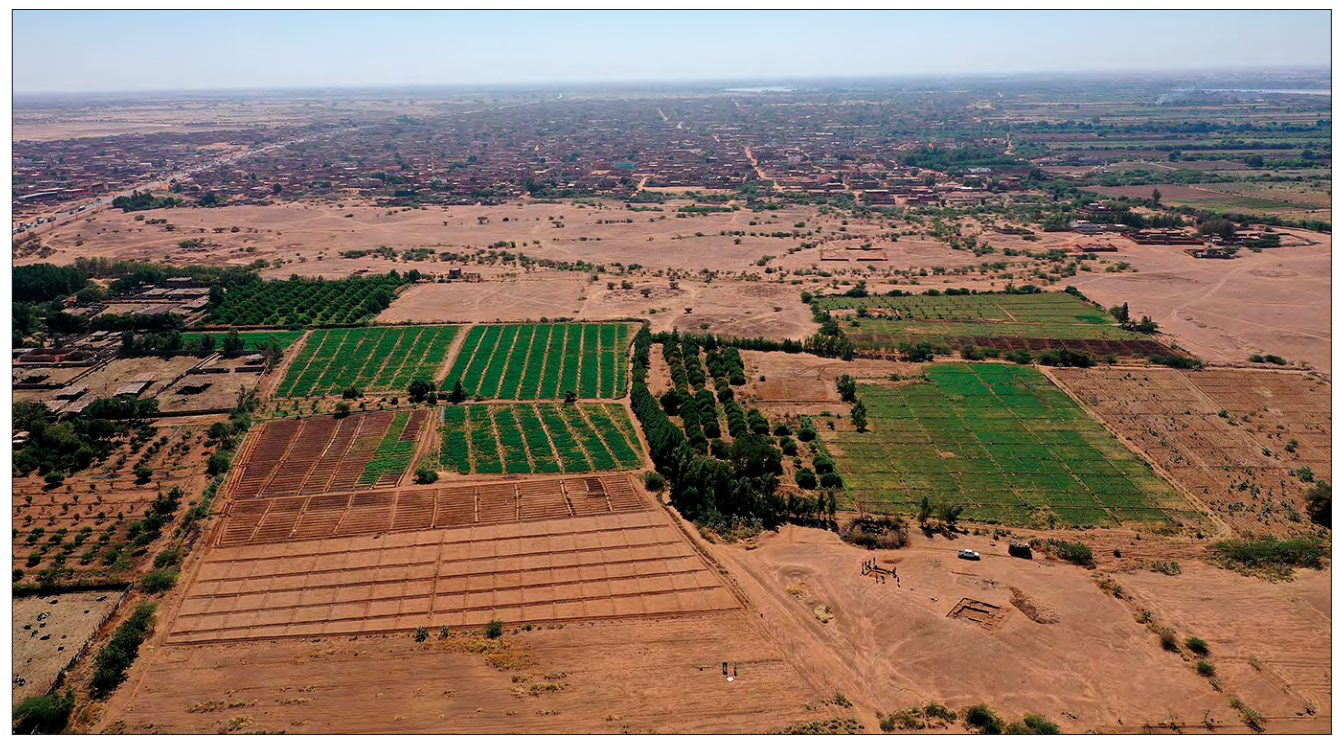

Fot. 3 Stanowisko z lotu ptaka, Soba (2019)

2 Nubia weszła w okres chrześcijański (V-XV w.) podzielona na trzy królestwa: Nobadii (Nuba) ze stolicą w Faras, między I a II-III kataraktą; Makurii (Mukurra) ze stolicą w Dongoli, aż po okolice między VI kataraktą a ujściem rzeki Atbary oraz właśnie Alodii (Alua) z Soba, sięgającą w pobliże posiadłości Aksum (Jakobielski 1996: 536). Alodia została schrystianizowana ok. 580 r. z inicjatywy dworu bizantyjskiego. Z czasem jednak miejscowy kościół uległ wpływom ośrodka aleksandryjskiego. Język grecki używany był w liturgii i prawdopodobnie na dworze. Arabscy pisarze zaliczali Alodyjczyków do Nubijczyków, podkreślali jednak ich afrykański charakter, jeśli chodzi o kulturę, jak i o wygląd. Nieliczne znane inskrypcje wskazują, iż posługiwali się dialektyczną odmianą nubijskiego (Obłuski 2017: 15-16). 
zakładami produkcyjnymi oraz dzielnicami mieszkalnymi, które zamieszkiwała mozaika ludów ówczesnego Sudanu. Soba upadła w dramatycznych okolicznościach, oblegana i zdobyta przez wojska Arabów Abdallab (Rufa) w 1504 roku. Następnie popadła w ruinę i do XIX wieku pozostawała bezludna (Drzewiecki, Ryndziewicz 2019: 316-317; Trimingham 1965: 74-75).

Pozostałości „Soby historycznej” - w większości pagórkowate usypiska z cegieł - przez długi czas były obszarem zwyczajowo chronionym, zaliczanym do kategorii bezludnej - harab czy nawet maskun („przeklętej”) - w opozycji do amar, obszaru zamieszkanego przez ludzi (fot. 3). To przestrzeń, w przypadku której - używając języka antropologii strukturalnej - mamy do czynienia z serią binarnych opozycji: haram - halal, duchowy - ludzki, gorący - zimny, pusty - zabudowany itd. Niewysokie ceglane pagórki, w tym jeden z kilkoma poprzewracanymi granitowymi kolumnami i kapitelami, niezliczone kawałki ceramiki, okresowe cieki wodne, pojedyncze, niewysokie akacje (acacia nilotica), w ich cieniu półdzikie psy, gdzieniegdzie kępki wysuszonej trawy, sterty śmieci i ekskrementy, jeden mały budyneczek będący siedzibą policji, od czasu do czasu przejeżdżający samochód, kilka tabliczek informacyjnych, żeliwne ogrodzenie oddzielające stanowisko archeologiczne od strony ulicy, jedno miejsce do modlitwy usytuowane w ogrodzie - to wszystko obrazy, które składają się na krajobraz "minionej”, ale też i po części „współczesnej Soby”. Fakt, że ruiny dawnej Soby zachowały się aż po XXI stulecie to spore zaskoczenie. $W$ drugiej połowie XX wieku rozmiar stanowiska, jak utrzymywali archeolodzy Peter Shinnie i Derek A. Welsby, był szacowany na jakieś 240-275 hektarów, teraz to zaledwie 53 hektary (informacja od Mariusza Drzewieckiego). Wszystko to za sprawą gęstej, podmiejskiej zabudowy, ale i pól uprawnych oraz ruchliwej asfaltowej drogi biegnącej do pobliskiego Chartumu. Prawdziwy przyrost osadnictwa w Soba („Soba współczesna”) przypada na lata dziewięćdziesiąte XX wieku. Zabudową mieszkalną objęto wtedy znaczną część dotychczas bezludnego terenu - zwłaszcza po wybudowaniu asfaltowej drogi (el-Gereif East - Eilafoun, która jest obecnie osią osadnictwa na tym obszarze. Po jej obu stronach powstał miejski targ (otwarty siedem dni w tygodniu) i kilka państwowych urzędów. Punktem centralnym jest stacja benzynowa. Przed kilkunastu laty przerzucono most nad Nilem Błękitnym, przez co rejon zyskał bezpośrednie połączenie z Chartumem. Wraz z osadnictwem postępowało przekształcanie tego obszaru (położonego najbliżej rzeki) w pola uprawne, a na początku XXI wieku rolnikom - przede wszystkim dużym właścicielom - udało się wejść w posiadanie nowych działek, otaczając część ceglanych pagórków z różnych stron. Część ziemi została zakupiona (wbrew prawu o ochronie zabytków), a część rolników dostała tylko pozwolenie na użytkowanie pod warunkiem, iż nie ma tam 
zabytków. Inni z kolei brali ziemię pod uprawę stosując metodę faktów dokonanych. Na granicy pól uprawnych powstały ceglane słupki, a następnie druciane ogrodzenia. Te jednak zaczęto przesuwać, metr lub dwa każdego roku. Pola są użytkowane za pomocą traktorów oraz intensywnie nawadniane. W rezultacie niegdyś pagórkowaty teren stał się płaski i oczyszczony z wszelkiego widocznego na powierzchni gruntu materiału archeologicznego.

„Soba miniona” jest dziś osią sporu, w którym pobrzmiewają takie problemy, jak prawa do ziemi, tożsamość grupowa czy dziedzictwo kulturowe (żeby wymienić tylko te najważniejsze). Aktorami w tym konflikcie, obok lokalnej społeczności, są archeolodzy, właściciele ziemscy i biznesmeni czy przedstawiciele sudańskich władz. Warto dodać, iż temperaturę sporu podgrzewają dokonujące się obecnie w Sudanie polityczne zmiany, które zapoczątkowało odsunięcie od władzy prezydenta Omara el Balszira w 2019 roku. Wszystko to sprawia właśnie, iż „Soba miniona” jest nie tylko fascynującym obiektem badań archeologicznych, ale także i etnograficznych.

\section{W cieniu piramid}

W minionych wiekach Soba była rezerwuarem budulca (charakterystycznej czerwonej cegły). To z rozbiórki ruin nubijskiej stolicy miał powstać w drugiej połowie XIX wieku pałac Generalnego Gubernatora w Chartumie. Później, wraz z okresem imperializmu europejskiego, Soba stała się źródłem zabytków archeologicznych (Drzewiecki, Ryndziewicz 2019: 317). Bohaterami tych utrwalonych w pamięci grupowej i w źródłach pisanych wydarzeń byli cudzoziemcy, postrzegani jako ci, którzy zawsze coś wywozili. Do tej grupy rozmówcy zaliczali także pracujących w tym miejscu w ostatnich dekadach archeologów. Najpierw byli to kolonizatorzy (przedstawiciele turecko-egipskiego i anglo-egipskiego Sudanu), a później władze już niepodległego Sudanu. W kontekście Soby nie sposób więc pominąć tematu imperialnej kradzieży. Dla mieszkańców Soba to dziedzictwo kulturowe, które poddawane jest systematycznej grabieży. Moi rozmówcy często podnosili tę właśnie kwestię, podkreślając, iż jest to działanie systemowe. Prace archeologiczne są tutaj pożądane, ale też łączą się z niebezpieczeństwem oskarżeń o szaber, imperializm czy nawet prozelityzm.

W Sudanie starożytności były obiektami nieustannego zainteresowania kolonizatorów, którzy niejako przywłaszczyli sobie przeszłość tego obszaru - w sensie symbolicznym i dosłownym. Sudan nie tyle był „bez historii”, ile nie był poddany właściwej (naukowej) historiozoficznej systematyce. Prace archeologiczne były prowadzone dla dobra dorobku cywilizacji, ale także po to, by Sudan wszedł na 
powrót w okres „złotego wieku” (czego omenem był jakoby Anglo-Egipski Sudan). W pierwszej kolejności badane były zatem ślady kultur inspirowanych starożytnym Egiptem i skoncentrowane w dolinie Nilu północnego Sudanu. Reszta kraju, gdzie nie było takich znalezisk, dziś pozostaje archeologiczną „białą plamą” (Abdelrahman, Welsby 2011: 24). Ruiny Meroe czy Dżebel Barkal urosły do rangi największych atrakcji turystycznych Sudanu. Równocześnie stanowiły kategorię klasyfikującą wytwory miejscowej kultury. Z tej perspektywy, wszystko co wydarzyło się później (po islamizacji i arabizacji tych obszarów), było źródłem rozczarowania, dowodem ulotności wielkich cywilizacji, Sic transit gloria mundi (Kurcz 2013). Stąd też m.in. tak trudno dzisiaj archeologom wzbudzić zainteresowanie zwykłych Sudańczyków innymi okresami dziejów ich kraju. W potocznej wiedzy z zakresu historii Sudanu poczesne miejsce zajmują bowiem wciąż pamiątki z czasów kuszycko-meroickich, strzeliste piramidy czy bogato dekorowane grobowce skalne. Zmiana konceptualizacji przeszłości wydaje się pożądana (i z punktu widzenia badaczy, i miejscowej ludności), nie jest jednak, z zasygnalizowanych powyżej powodów, sprawą łatwą do zrealizowania.

\section{Soba jako miejsce pamięci i nie-pamięci}

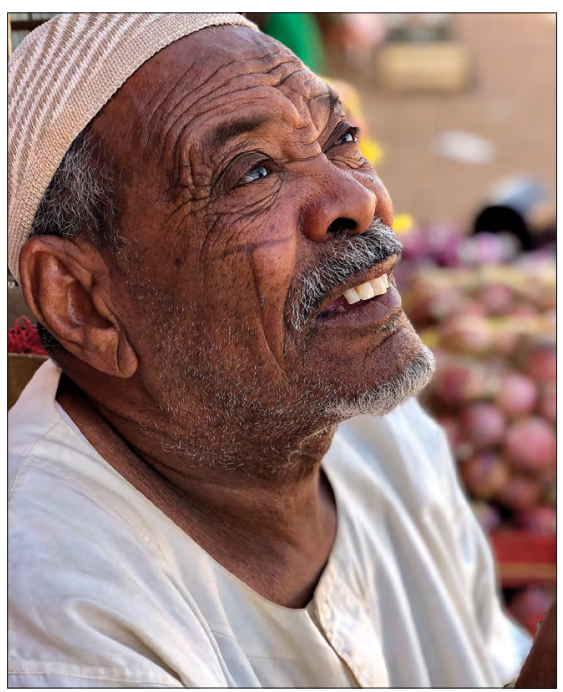

Fot. 4 Przedstawiciel zasiedziałej ludności Soby - Arabów Mugarba, Soba (2019)
Pamięć kulturowa mieszkańców jest niezbyt długa. Wiąże się z „intymnymi” i „krewniaczymi” więzami. To pamięć o przodkach, przywódcach rodowych czy plemiennych, świętobliwych mężach, migracjach czy zmianach ekologicznych. Soba historyczna nie zajmuje żadnego istotnego miejsca w pamięci. To miejsce bezludne, gruzowisko kamieni i cegieł z kategorii harab. Twórców nubijskiego królestwa, inaczej niż na obszarach północnego Sudanu, nie uważa się za realnych przodków (antenaci najstarszej grupy ludności - Arabów Mugraba - osiedlili się w Soba zaledwie pod koniec XIX wieku). W przeciwieństwie na przykład do Starej Dongoli, Abkur czy innych opustoszałych obszarów osadniczych północnego Sudanu, Soba nie jest miejscem ważnych dla lokalnej społeczności rytuałów pamięci³. Według mieszkańców Soba

3 Np. w Starej Dongoli w czasie „Wielkiego Święta” odwiedzane są stare cmentarze - w szczególności grobowce świątobliwych mężów. Na co dzień miejsce to jest częścią Pustyni Nubijskiej, 
to miasto ceglanych kościołów; zostało zdobyte na początku XVI wieku przez koalicję Arabów Abdallab oraz Fundż, którzy zapoczątkowali w Sudanie nastanie zupełnie nowej ery. W tym przypadku mamy do czynienia raczej z nie-pamięcią ${ }^{4}$.

Nasze badania wskazują, iż Soba jest zarazem miejscem nie-pamięci, jak i pamięci. W szczególności wśród przedstawicieli grup elitarnych (dawnych tradycyjnych przywódców, nielicznej inteligencji), a należących do zasiedziałych mieszkańców - możemy mówić o pewnego rodzaju dumie wobec tego miejsca (fot. 4). Dość wspomnieć, iż jedna z miejscowych podstawówek nosi nazwę „Królestwo Soby". Powodem do dumy jest fakt, iż współczesna Soba leży w miejscu dawnej stolicy nubijskiego królestwa. Wzmacniają ją regularne kontakty mieszkańców ze śladami archeologicznymi. Każdy z moich rozmówców, zarówno dzieci, jak i osoby starsze, w swoim życiu miały styczność z zabytkami. O śladach archeologicznych przypominają każdorazowo prace budowlane i powodzie, właściwie corocznie odsłaniające kości czy skorupy. Odnajdowane zabytki są dowodem potęgi i bogactwa żyjących tam niegdyś ludzi.

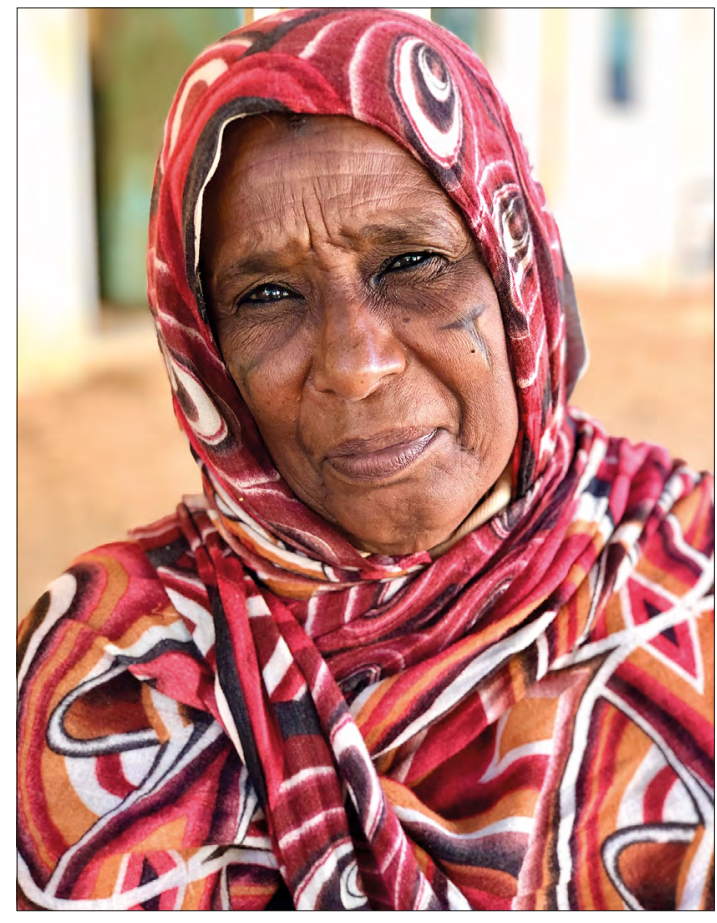

Fot. 5 Kobieta ze społeczności Arabów Mugarba,

Soba (2019) Dla mieszkańców współczesnej Soby są to „przedmioty pamięci”, które odsyłają do przeszłości i uruchamiają pamięć. Malowana ceramika, duże wypalone cegły czy różnego rodzaju przedmioty codziennego użytku, to wszystko są heterogeniczne symbole, nieme świadectwa przeszłości, które „przemawiają” do ludzi. Prace archeologiczne jeszcze zdynamizowały ten proces. Zabytki są ważne, ponieważ stymulują do refleksji i dyskusji na temat życia przodków oraz przedmiotów przez nich używanych. Przede wszystkim jednak są dowodami szczególnej wielopokoleniowej ciągłości. Ta z kolei jest atrybutem ludzi z długim rodowodem, których pamięć jest głęboko zakorzeniona i solidnie

rzadko kiedy spotkać w nim można człowieka, w czasie świąt zapełnia się ludźmi w odświętnych strojach, przynoszących ze sobą świeżo ścięte gałązki palm (zob. Kurcz 2007).

4 Przez pojęcie to rozumiem brak materialnych czy instytucjonalnych podstaw, dzięki którym ludzie mogą odnosić się do odległych w czasie epok. 
historycznie obwarowana. Jest to o tyle prostsze, iż dawni mieszkańcy Soby używali przecież niemalże tych samych przedmiotów (żarna, kamienie młynne, duże zasobowe naczynia etc.), co obecnie żyjący mieszkańcy tego terenu.

Ruiny Soby są „nasze” przede wszystkim jednak w sensie mitycznym, pozbawionym jakichkolwiek konotacji z porządku historii - byli to przecież Nubijczycy (nazywani w tym przypadku najczęściej: „Amadż”) i w dodatku chrześcijanie. Historyczna Soba została więc selektywnie inkorporowana do kolektywnej pamięci - zwłaszcza Arabów Mugarba (fot. 5) - pełnej chwalebnych czynów i przynależnego im, ich zdaniem, naturalnie wysokiego statusu, zwłaszcza od XVI wieku po schyłek epoki kolonialnej. Soba pełni w tym wszystkim rolę pewnego rodzaju punktu wyjścia, początku historii, jest rodzajem genesis.

Historia i pamięć to dwie różne formy odnoszenia się do przeszłości. Historia jest dyskursem fachowców, opowieścią oficjalną. Pamięć z kolei jest tym, co widziało się na własne oczy albo słyszało się od poprzednich pokoleń, czy - jak kto woli - niosła „Iudowa lutnia”. Dla tego typu relacji z przeszłością szczególnie ważne okazują się gest, symbol, obraz czy mit (Nora 2009: 4-12; Goody 2012: 112-132).

Przykładem tego rodzaju odwołań do przeszłości jest dla mnie to, co nazywam legendą o Adziobie - kobiecie, która doprowadziła do upadku Soby (Adzioba zniszczyła Sobę). Adzioba miała być królową Soby (według innych wersji wiedźmą czy po prostu zwykłą kobietą). Wszyscy natomiast zgodni byli co do tego, że miała piękną córkę o imieniu Tajiba. O rękę córki starało się wielu okolicznych królów (niektórzy twierdzą, że byli to raczej ministrowie czy szlachetnie urodzeni mężowie). Jej matka była jednak chciwa i podstępna. Od każdego kandydata żądała wielkiej ilości złota, ale także tego, by każdy kolejny konkurent zabił poprzedniego. W ten sposób zginąć miało wielu mężczyzn, a w kraju zapanował chaos. W końcu jednak ktoś wydał sekret królowej, a okoliczne plemiona, z Fundż i Abdallab na czele, zjednoczyły się i zaatakowały Sobę. W ten oto sposób doszło do całkowitego zniszczenia Soby.

Opowieść ta gatunkowo mieści się w kategorii różnego rodzaju narracji. Po części może być uznana za legendę, po części także za bajkę. Legenda w warunkach społeczeństw plemiennych przybiera najczęściej postać historii klanowej czy dynastycznej (Goody 2012: 192). Może być także utkana na kanwie jakiegoś przełomowego wydarzenia, jak właśnie zdobycie - upadek Soby. Poniekąd może być także uznana za bajkę, czyli opowiadanie przeznaczone raczej dla dzieci i mające charakter przestrogi. Sudańska bajka ma charakter nieodmiennie edukacyjny, ukazują się w niej, niejako jak w krzywym zwierciadle, dobre i złe cechy

5 To ogólne określenie używane w centralnym Sudanie na ludność niearabską. 
człowieka. Skromność, prawdomówność, dobroduszność, szacunek wobec starszych należą do najczęściej spotykanych odniesień moralnych w sudańskich „bajkach dla dzieci". Opowiadają je kobiety swoim małoletnim podopiecznym w czasie wiejskich wieczornic. Noc jest warunkiem sine qua non tego typu opowieści, a za jego złamanie mają grozić nadprzyrodzone sankcje. To „babskie bajdurzenie", przybierające różnoraką postać, od słownych zagadek po bajki, nazywa się hudża, tj. mądrość (Abdulla 1955: 65-69).

Cóż więc w gruncie rzeczy mówi nam ta niezbyt długa opowieść? Zwrotu „Adzioba zniszczyła Sobę" używa się, gdy ktoś (zwłaszcza jeśli jest to kobieta) zrobi coś sromotnie niszczycielskiego. Niektórzy byli także zdania, iż można go używać jako ostrzeżenia przed utratą z pola widzenia czegoś ważnego. Może to doprowadzić do nieszczęścia: podczas gdy mieszkańcy królestwa „zabijali się" o piękną kobietę, u ich wrót pojawiło się śmiertelne niebezpieczeństwo. Na myśl przychodzi także interpretacja mizoginiczna. Kobieta jest sprawczynią upadku całych królestw. Może być tajną, podstępną bronią, a jej orężem staje się zazwyczaj uroda i powab. Jest piękna i pociągająca, ale równocześnie wywołuje chaos; może stać się zła, wręcz demoniczna. Taki model kobiecości opisywany jest dość często w sudańskim folklorze. Wątek mizoginiczny jest bardzo czytelny także w wersji teatralno-telewizyjnej, w opowieści autorstwa Khalid Abu-Al Rousèa. Adzioba jest w niej podstępną, starą kobietą (żeby nie powiedzieć wiedźmą), która pod pretekstem zemsty sieje zniszczenie (doprowadza miasto do ruiny) i dąży do zabicia władcy. Wykorzystuje przy tym jakoby typową dla swojej płci broń - „strzałę amora”. Jest wysoce prawdopodobne, iż bajka/legenda o Adziobie nabrała z czasem nowego, uniwersalnego znaczenia, konotując niszczycielską naturę kobiety, czego dobitnym przykładem jest współczesna, telewizyjno-teatralna adaptacja tej opowieści.

Być może historia ta, to także komentarz na temat ekspansji Arabów i islamu w Sudanie, która dokonywała się przy pomocy małżeństw i przejścia z systemu matry- do patrylinearnego. W historii tej może być ukryty również motyw, dla którego Arabowie dokonali podboju Soby. Yusuf Fadl Hasan, bazując na tradycji ustnej i pisanej wspomina, iż Arabowie zjednoczyli się pod kierownictwem Abdallab, żeby przeciwstawić się tyranii „królów Anadż” (Hasan 2005: 132-133). Przy czym miała być to tyrania w sensie jurysdykcji obcej i co najważniejsze - chrześcijańskiej władzy, ale także władzy per se - używającej swoich zwykłych prerogatyw, jakim są na przykład podatki. Hipoteza ta jest tym bardziej prawdopodobna, ponieważ przemawia za nią warstwa symboliczna opowieści, znów silnie umocowana w folklorze. Adzioba - jak wiele innych bajkowych postaci kobiecych - należy do świata archaicznego, sprzed ostatecznego zwycięstwa islamu; stoi w opozycji do 
teraźniejszości i cywilizacji. Ten sam motyw reprezentuje w północnosudańskim folklorze postać „niebogobojnej” czy „chrześcijańskiej dziewczyny”. Są to postaci symbolizujące zamierzchłe, archaiczne czasy. Zabicie Adzioby i zdobycie Soby mogą być zatem odczytywane także jako swego rodzaju "wyjście z puszczy” (the end of wilderness).

\section{Wykopaliska i archeolodzy}

Do archiwum zbiorowej pamięci należą szczególnie niszczycielskie powodzie (1946, 1988, 2013), które przeszły przez Sobę. Są to ważne cezury, do których mieszkańcy odwołują się w intymnych, krewniaczych historiach, pełnych cierpienia, ale także i heroizmu. W strukturze pamięci ważną rolę odgrywają również minione kampanie archeologiczne. Są to opowieści o cudzoziemcach: codziennych kontaktach, w tym także przyjaźniach, godziwym zatrudnieniu i związanych z nim korzyściach (zakupie dóbr konsumpcyjnych).

Soba z racji bliskości Chartumu była częstym miejscem wycieczek cudzoziemców. W tradycji ustnej zachowały się wspomnienia polowań czy wycieczek na wielbłądach. W czasach kolonialnych Soba stała się także obiektem zainteresowań archeologów. Pierwsze prace archeologiczne prowadzono tam już na przełomie XIX i XX wieku (J. Dumichen, E.A.E. Stanton, E.A.W. Budge i S. Clarke). Z czasem stanowisko archeologiczne objęto nadzorem Sudańskiej Służby Starożytności (Sudan Antiquities Service). Mianowano lokalnych strażników, opłacanych z państwowej kasy. Według rozmówców, byli to ludzie cieszący się dużym szacunkiem, jak na przykład Atigal Mahomed Abu Kerra, który znany był ponoć z tego, iż potrafił rozpoznawać ludzi po śladach stóp na piasku. Postacie te zajmują stałe miejsce w pamięci kulturowej.

Z ramienia Sudańskiej Służby Starożytności w latach 1950-1952 prowadzono zakrojone na szeroką skalę prace pod kierownictwem Petera Shinnie. Między 1981 a 1991 rokiem zwiad powierzchniowy i wykopaliska prowadził Derek A. Welsby. Z oczywistych względów miejscowa ludność najbardziej pamięta tę właśnie kampanię badawczą Wielu mężczyzn brało w niej udział jako robotnicy. Rozmówcy wspominali organizację pracy, zarobki, spotkania towarzyskie oraz miejsca prowadzenia badań. Do dziś krótkie spodnie nazywa się w tej okolicy - od imienia kierownika prac - "derek”. Pamięta się także, iż jeden z robotników, gdy został zwolniony, zyskał przydomek „Finish”. Zabytki pamiętane są niezbyt dokładnie, wymieniane były najczęściej znane i używane w Sudanie gliniane naczynia. W rozmowach pojawiały się także wątki mityczne, jak choćby kwestia ukrytych skarbów, o czym dalej. 


\section{Materialne pozostałości przeszłości}

Permanentna kohabitacja mieszkańców Soby ze śladami archeologicznymi jest faktem. To efekt budowy domostw na obszarze występowania struktur archeologicznych. Można przypuszczać, iż decyzje o stawianiu domów podejmowano świadomie, mimo prawnych i zwyczajowych zakazów. Obszar ten, jak już pisałem, przez stulecia pozostawał bezludny, a początkowo osadnictwo rozwijało się wyłącznie na jego obrzeżach. Jednocześnie był to postępujący proces (fot. 6). Obejmował coraz większą powierzchnię archeologicznego stanowiska.

Stosunek do artefaktów archeologicznych jest bardzo różny. W przypadku budowy domostw jest to problemem, który trzeba dyskretnie rozwiązać. Kości i ceramika wyrzucane są do pobliskiej doliny rzecznej lub na nieformalne wysypiska (zabytek jako odpadek). Wyczuwa się obawę przed powrotem archeologów i wywłaszczeniami. Paradoks - równocześnie opowieści o zabytkach są częścią historii każdego domu i chętnie się do nich wraca. Zawsze coś napotykano - kości czy ceramikę, zazwyczaj przy budowie toalety, ewentualnie niwelowaniu terenu pod fundamenty czy po szczególnie obfitej porze deszczowej. Mieszkańcy otwarcie się do tego przyznawali w trakcie prowadzonych badań terenowych. Od razu jednak wszyscy zaznaczali, iż teraz jest wolny od jakichkolwiek zabytków. Sprawa jest zamknięta. Mamy tutaj do czynienia także z pewnego

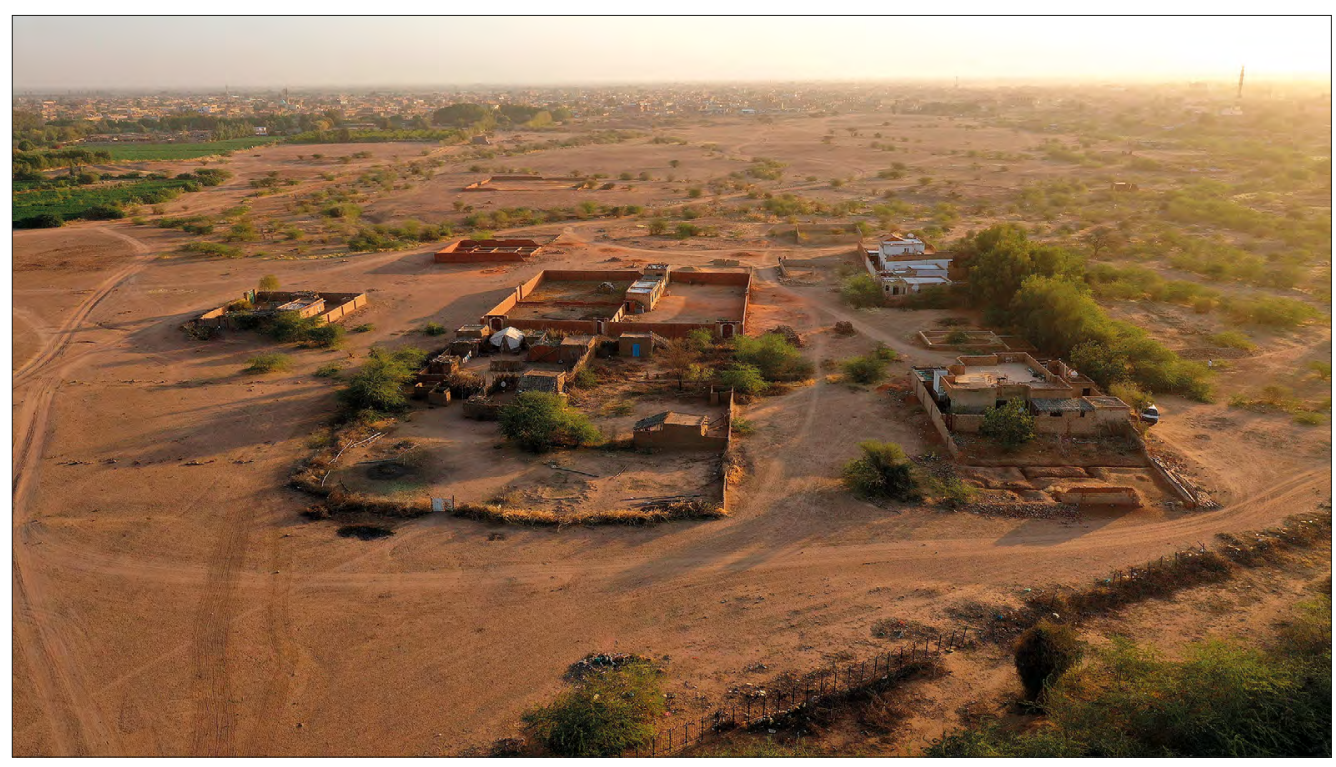

Fot. 6 Serce średniowiecznej Soby z lotu ptaka (2019) 
rodzaju lękiem. Zabytek może sprowadzić na człowieka formalno-prawne kłopoty. Zdaniem mieszkańców może stać się powodem eksmisji lub znacznie utrudnić prowadzoną ekonomiczną działalność. Ze względu na traktowanie zabytku jako odpadek, możemy mówić o pewnego rodzaju kontinuum. Zabytek - śmieć, stanowisko archeologiczne - wysypisko śmieci (rozumiane zresztą tak w sensie literalnym, jak i metafizycznym). W rezultacie stanowisko archeologiczne należy postrzegać jako swoistą przestrzeń liminalną w całej rozciągłości. W lokalnej „geografii mistycznej" posiada status nieczystości, marginalności. Jest to także teren niebezpieczny - ta cecha to zasługa nocnych amatorów alkoholu czy narkotyków, ale także pospolitych złodziei i włóczęgów. Ważne także w tym względzie okazują się konotacje ze śmiercią. Stanowisko archeologiczne definiowane jest bowiem w pierwszym rzędzie jako przestrzeń śmierci - terra morta. Jest jednym wielkim cmentarzyskiem, które właśnie dlatego pozostawało przez stulecia niezamieszkałe. Przynależy bowiem do innego świata. Wyobrażenie to ugruntowane jest niezliczonymi wręcz przypadkowymi odkryciami szczątków ludzkich oraz historiami z nimi związanymi. Niewykluczone także, iż obszar historycznej Soby pełnił rolę miejsca pochówkowego (o bliżej nieokreślonym statusie) aż do czasów

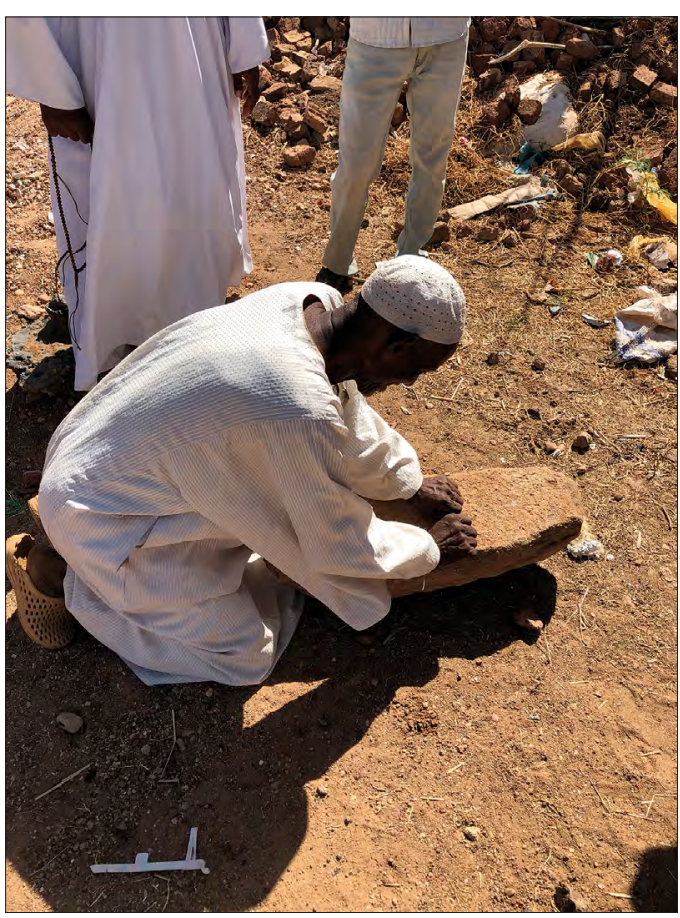

Fot. 7 Mężczyzna prezentuje rozcieracz pochodzący ze średniowiecznych ruin, Soba (2019) mnie więcej współczesnych. Wątek ten jednak musi być potwierdzony na drodze dalszych badań archeologicznych i etnograficznych.

Nie zawsze jednak zabytków się pozbywano. Przynajmniej nie wszystkich. Powszechnym uznaniem cieszą się charakterystyczne duże i czerwone cegły. Niewiele co prawda można ich dzisiaj zobaczyć na terenie domostw. Wykorzystywane są jednak do wznoszenia fundamentów. Znacznie częściej spotkać je można na pobliskich cmentarzach. Zostały re-użyte do „obstawienia” mogił oraz jako stele nagrobne (szczególnie duże cegły z warstwą tynkową - cmentarz szejcha Wad Tarafa). Podobnie jest z blokami kamiennymi używanymi w średniowiecznych budowlach w dolnych częściach. Zobaczyć je było można kiedyś jako wzmocnienie murów czy kamienie graniczne. Nawet ceramika znajduje zastosowanie przy łataniu dziur w różnego rodzaju budowlanych konstrukcjach (zabytek jako materiał). 
Niektóre przedmioty, głównie ze względu na podobieństwo z jeszcze używanymi na prowincji sprzętami, przywracane są do życia (fot. 7) Dotyczy to na przykład różnej wielkości rozcieraczy - jak choćby tzw. murhaga. Znaleźć je można nadal w wielu domach - przynajmniej niedawno należały jeszcze do kuchennego inwentarza. Ich rola, jak na razie, jest trudna do określenia. Być może przeważają w tym przypadku względy sentymentalne, a artefakty te należy traktować metaforycznie jako łączniki między minionymi i teraźniejszymi pokoleniami, za pomocą których materializuje się pamięć. Do niektórych, o czym wspominałem, przemawiają jako spuścizna minionych poko-

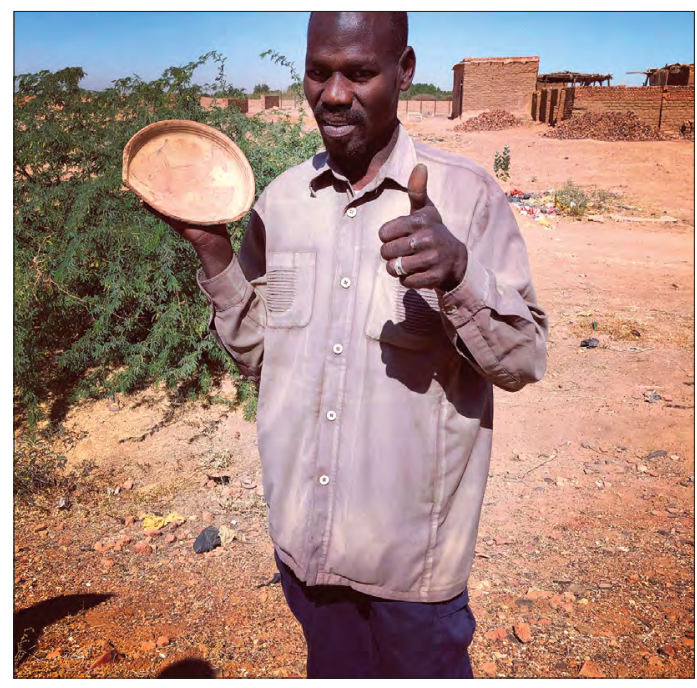

Fot. 8 Mężczyzna ze swoim znaleziskiem, Soba (2019) leń - dowód swoistości mieszkających tam nie-

gdyś ludzi: znaki przeszłości, symbole przodków, kulturowych początków, mitycznych bohaterów, czcigodnych przodków, krótko mówiąc - dziedzictwo kulturowe. Zapewne zjawisko to będzie się zmieniało pod wpływem prowadzonych archeologicznych prac. Podobnie jest z ceramiką - zwłaszcza tą malowaną. Naczynia ceramiczne lub ich fragmenty traktowane są często jako ciekawostki i eksponowane są w salonie czy na podwórzu. To z kolei wiąże się z pojmowaniem zabytku jako przedmiotu posiadającego walory estetyczne (zabytek jako przedmiot estetyczny) (fot. 8). Relikty przeszłości mogą być wreszcie przedmiotami świętymi (zabytek jako przedmiot święty - w sensie dobrym i złym) i mieć duchową moc. Mogą to być różnego rodzaju monety czy kawałki ceramiki używane jako talizmany (monety przytwierdzone do weselnej spódniczki czy odświętnego moździerza). Inaczej dzieje się z kośćmi ludzkimi - traktowane są z bojaźnią i wyrzucane lub przenoszone w inne miejsce. Być może są one przedmiotami praktyk czarnomagicznych - sprawa ta wymaga jednak dalszych badań.

\section{Wątek złota i wierzenia ludowe związane z archeologicznym stanowiskiem}

Mieszkańcy Sudanu mają ma wręcz obsesyjny stosunek do złota. Geneza tego zjawiska jest złożona i wymaga paru słów wyjaśnienia. Złoto - jak wiadomo - jest zwyczajowym darem przekazywanym dziewczynie i jej rodzinie z okazji ślubu. W tym sensie Sudan nie odbiega od innych krajów muzułmańskich, gdzie obowiązują wciąż sformalizowane opłaty małżeńskie. Semantyka złota wzmocniona 
jest tutaj także poprzez mit Sudanu jako kraju złotonośnego, w rodzaju mitycznego eldorado. Na ten fakt ma również wskazywać etymologia słowa Nubia (od nob, nab, co w nubijskim języku oznaczać miało „ten metal”) (Ali Osman 1992: 34). Mit złota nawiązuje zwłaszcza do czasów faraońskiego Egiptu oraz starożytnych królestw Kusz i Meroe. Wierzy się, iż w minionych epokach wydobywano ogromne ilości złota, stąd ten kruszec łączy się w Sudanie powszechnie ze starożytnościami. Popularne przysłowie mówi „Stare jest złotem”, ślady archeologiczne zaś w powszechnej opinii symbolizują złoto - zwłaszcza te pochodzące z okresu kuszycko-meroickiego (Ali Osman 1992: 33). Tak naprawdę jednak funkcjonuje przekonanie, iż wśród każdych ruin ukryty jest baśniowy skarb. Strzegą go jednak nadprzyrodzone istoty: diabły, węże, psy, koty, złowrogie miraże czy inne poślednie duchy. Każdy skarb ma swojego strażnika. Nie inaczej jest w przypadku Soby. Stanowisko archeologiczne to miejsce tajemnicze, magiczne, które upodobały sobie różnego rodzaju siły nadprzyrodzone. Strzegą one tajemnic tego miejsca przed rabusiami przeszłości. Wspólnym ich mianownikiem jest czasoprzestrzeń nocy - pory graniczne: zmierzch, północ czy pora tuż przed świtaniem. Niektórzy rozmówcy wspominali także o tym, że pojawiały się w południe (czyżby także i tutaj istniała wiara w południce?). Warto dodać, iż noc to czas jakościowo inny od dnia. Nadaje się w niej rzeczom czy zjawiskom inne znaczenie, np. dziwny dźwięk czy zwierzę mogą stać się źródłem metafizycznego strachu. Powszechna jest wiara w zjawisko o nazwie ablemba, to znaczy „światło”, "lampa”. To miraż wywodzący się zapewne ze świata nomadów, ma odciągać ludzi od domów czy utartych ścieżek. Równie popularna jest wiara w spotkania z tajemniczymi zjawami - głównie kobiecymi - które jednak tak szybko znikają, jak się pojawiają. Niektórzy wspominali, iż duchy te mają pochodzenie chrześcijańskie („chrześcijańskie diabły i duchy” - mówiono). Walka z nimi ma być szczególnie trudna, gdyż nie są posłuszne słowom Koranu. Ruiny mają także swojego strażnika. Jest nim jednooki dżinn, nigdy nie obraca się plecami. Wszystko ma dzięki temu w zasięgu wzroku. Inni rozmówcy wspominali także o wielkim wężu, który emituje światło (motyw „lampy”) i tym samym przyciąga do siebie swe ofiary. Na obszarze ruin przebywają także dżinny, które mogą okazać się pomocne ludziom. Trzeba jednak posłużyć się czarną magią - tzw. amal. Za pomocą określonych koranicznych sur przywołuje się ducha. Ten wtedy może spełnić każde życzenie, w tym wskazać miejsce, gdzie ukryty jest mityczny skarb. Ważne by pamiętać jednak, iż trzeba coś w zamian obiecać (motyw symbolicznego daru, jak w przypadku wizyty w kubbie - lokalnym sanktuarium). Wierzy się także w istnienie magicznego wejścia znajdującego się przy jednym z pagórków z cegieł. Jest to miejsce bliżej nieokreślone. Można przez nie wejść 
do innego świata. Ci, którzy znaleźli to przejście, nigdy jednak nie wrócili lub znaleźli się w zupełnie innym miejscu i postradali rozum.

Mit złota funkcjonuje też w kontekście prac archeologicznych. Właściwie każde prace archeologiczne stają się częścią serii opowieści o złocie, zawsze budowanych według scenariusza: cudzoziemcy - poszukiwania - tajemnica - zabranie skarbu. W przypadku każdej ekspedycji powtarzana jest ta sama opowieść. „Gdy znajdowaliśmy coś, byliśmy przeganiani. Wszystko następnie było zabierane do Chartumu. Nie wiemy, co znaleziono. Być może były to skarby" - to słowa jednego z informatorów.

Osobnym gatunkiem miejscowego folkloru są „straszne opowieści”. Ich scenerią jest obszar wioski. Również w przestrzeni „oswojonej” znajdują się miejsca uważane za niebezpieczne. To różnego rodzaju wysypiska śmieci czy opuszczone domy. To także miejsca położne na skraju zabudowy. Każda okolica posiada takie przestrzenie. W nocy będzie się ich zdecydowanie unikać. Jak wspominałem, dla niektórych z naszych rozmówców cała wioska jest miejscem potencjalnie niebezpiecznym. Pracom budowlanym towarzyszą dziwne wydarzenia interpretowane jako ingerencja sił nadprzyrodzonych - np. jeden z robotników był świadkiem, jak jego koparka po prostu stanęła przy kopaniu fundamentów. W rozwiązaniu problemu pomogła dopiero wizyta szejcha i recytacja Koranu.

\section{Negocjowanie z obyczajem i religią}

Moją uwagę zwróciła także historia o "złym domu” (beit maskun), a dotyczyła ona konkretnej, niezamieszkałej budowli. Jej złowrogi charakter potwierdzili wszyscy okoliczni sąsiedzi. Ludzie łączyli go jednak z różnymi dziwnymi paranormalnymi zjawiskami: uczuciem bliskości jakiejś niewidzialnej istoty, niepokojącymi dźwiękami, płaczem dziecka, lewitowaniem przedmiotów, obecnością różnych nieprzyjaznych człowiekowi gadów. Opowiadano, że w miejscu domu stało kiedyś duże drzewo, stare i częściowo uschnięte. Właściciel ściął je, a na jego miejscu wzniósł dom. Nie nacieszył się nim jednak długo. Po kilku dniach opuścił go i nigdy do niego nie wrócił. Ponoć nie dało się w nim mieszkać, a jego rodzinę dotknęła seria nieszczęśliwych zdarzeń. Następny właściciel też miał wkrótce umrzeć. Kolejny „nawiedzony dom” usytuowany był w zupełnie innej części wioski - w okręgu Salama. W jego przypadku powodem opętania był dżinn o imieniu Tahun. Pojawił się, gdy ktoś zabił w tym miejscu węża. Duch długo dawał się we znaki domownikom (np. bił ich), by zostać egzorcyzmowany za pomocą Koranu przez jednego z szejchów. Podobno takich domów jest więcej. Niektórzy rozmówcy uważają, iż ze względu na usytuowanie zabudowy wśród ruin Soby, cała wioska jest nawiedzona przez „szatana”. 
Wiara w tego typu zjawiska nie jest czymś wyjątkowym. Także motywy starego drzewa jako siedliska psotnego ducha lub węża - zwłaszcza kobry, spotkać można w folklorze całego północnego Sudanu. W tym drugim przypadku mamy od czynienia ze swoistym totemicznym tabu. Opowiadano nam historię mężczyzny, który ma na swojej farmie węża, którego karmi, ten zaś opiekuje się jego polem. Kiedyś w okresie szczególnej posuchy przyniósł mu złoto, dzięki czemu ów człowiek nie umarł z głodu. Z kolei gdy inny mężczyzna zabił węża - rozstąpiła się pod nim ziemia i stanął przed sądem złożonym z dżinnów. Zbrodnie mu wybaczono, ale zamienił się w starca. Tego rodzaju opowieści mogą pełnić jeszcze inną rolę. Teren, na którym znajduje się wspomniany jako pierwszy „nawiedzony dom”, do niedawna leżał jeszcze na terenie bezludnym i był integralną częścią stanowiska archeologicznego. Obszar ten był więc, jak informowałem, zwyczajowo zakazany i kojarzony ze światem nadprzyrodzonym. Obyczaj mówi, iż nie wolno naruszać spokoju takich miejsc. Nie powinno się stamtąd także niczego zabierać ani niczego tam budować. Przypominają one swym statusem cmentarze. Są to miejsca pamięci o przodkach i ich kulturze. Ważne są dla ludowej konceptualizacji przestrzeni i serii binarnych opozycji - żeby posłużyć się znów językiem antropologii strukturalistycznej. W przypadku Soby presja demograficzna okazuje się jednak silniejsza. Nowi migranci decydują się budować na obszarach dawnych ruin, zagarniając coraz większe obszary archeologicznego stanowiska (mimo dezaprobaty zasiedziałych mieszkańców, którzy paradoksalnie kiedyś uczynili dokładnie to samo). Opowieści o wrogich, nadprzyrodzonych siłach, które nawiedzają ludzkie domostwa mogą być w tym przypadku rodzajem mediacji, a dokładniej - ceną za złamanie zwyczajowego tabu. Ta wydaje się jednak niezbyt wygórowana. Nadprzyrodzona kara dotyka przecież tylko niektórych - mitycznych kozłów ofiarnych, którzy złamali jakieś tabu (wycięli drzewo czy zabili jakieś zwierzę - lokalnego ducha opiekuńczego). Historie takie mogą dawać ludziom osiedlającym się w Sobie komfort wobec obyczaju i religii, stanowić formę negocjacji ze światem duchowym.

\section{Etnografia i archeologia}

Etnografia, jak się zdaje, może wskazywać na kilka odniesień konceptualnych dotyczących badań archeologicznych. I tak, swego rodzaju etnograficzne spojrzenie może posłużyć do prześledzenia procesu wytwarzania wiedzy przez archeologów przy samej „krawędzi kielni” lub pomóc w zrozumieniu miejsca projektu archeologicznego w szerokim spektrum zjawisk z dziedziny nauki, ale także i socjopolityki. Wreszcie etnografia może być niezwykle użyteczna w doprecyzowaniu takich kluczowych dla dzisiejszych prac archeologicznych kwestii jak: wpływ, odbiór, zasięg czy odbiorca (Castañeda 2008). Chodzi tu o wyjście archeologów i archeologii 
w stronę interesariuszy ze społeczności lokalnej, która dzierży palmę pierwszeństwa w prawach do stanowiska i znajdujących się tam materialnych śladów przeszłości. Etnografia może pełnić rolę narzędzia „społecznego dostępu” do dziedzictwa archeologicznego, a także wzbudzenia zainteresowania nim6. Z perspektywy Sudanu właśnie ta ostatnia wiązka problemów wydaje się szczególnie istotna i interesująca.

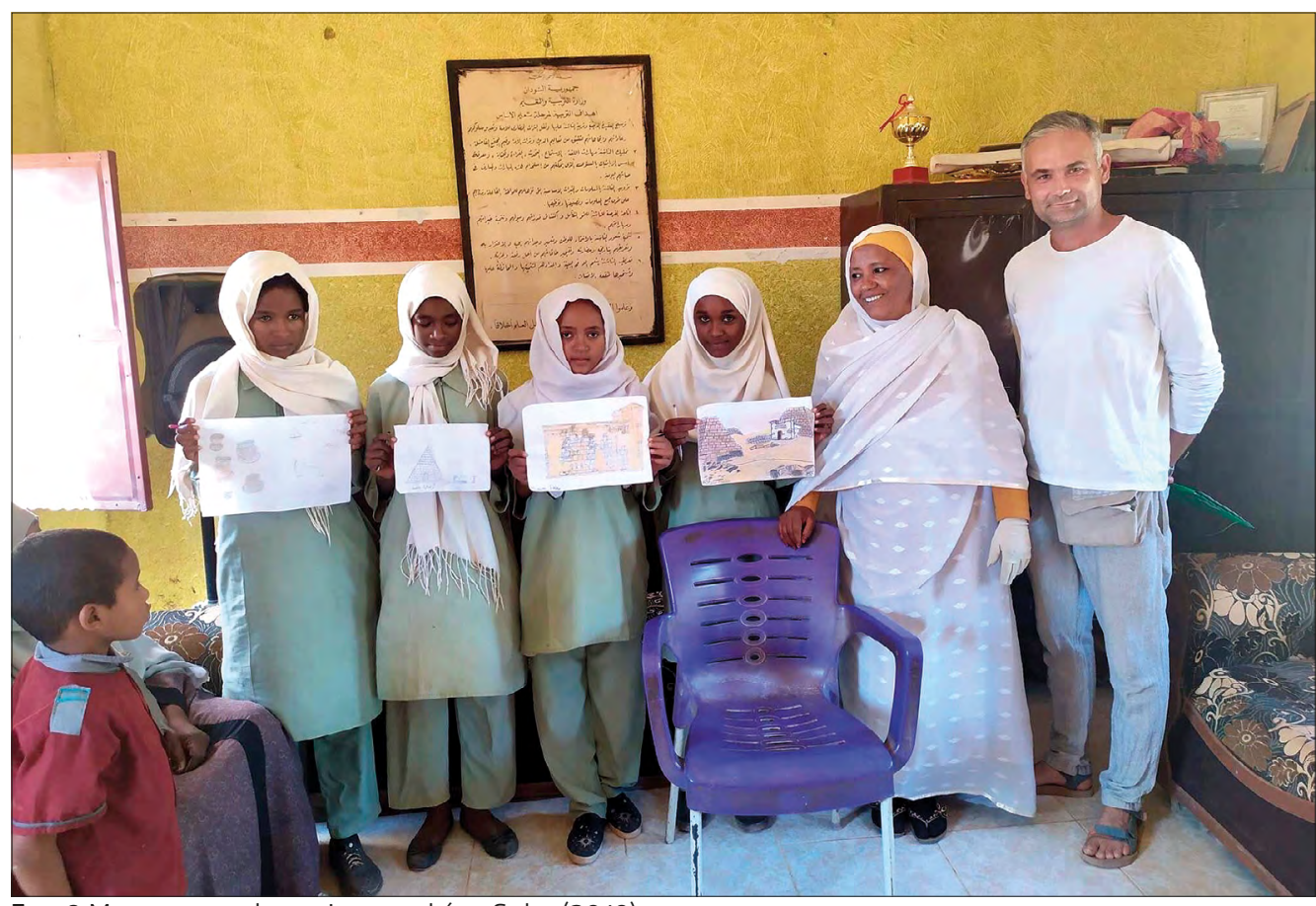

Fot. 9 Moment przekazania rysunków, Soba (2019)

Poszukując kontaktu z lokalnymi interesariuszami, za centra naszej badawczej działalności przyjęliśmy targowe herbaciarnie, meczety i domy największych właścicieli ziemskich. Na mapie naszej aktywności nie zabrakło także szkoły. Za grupę fokusową obraliśmy społeczność publicznej szkoły podstawowej w Gana’ab - regionie Soby najbliżej położonym względem stanowiska archeologicznego. W 2019 roku placówka posiadała 620 uczniów i dwudziestoosobowe grono nauczycielskie. W czasie dwóch spotkań z nauczycielami i ich podopiecznymi (wyłącznie z żeńskiej części żeńskiej szkoły) rozmawialiśmy o pracy archeologa i ruinach średniowiecznej Soby. Na zakończenie dzieci poproszone były o przygotowanie rysunków - pocztówek, przedstawiających zabytki Sudanu, które następnie miały być zabrane

6 Więcej na ten temat zob. Johnson (2013), Castañeda (2008). 


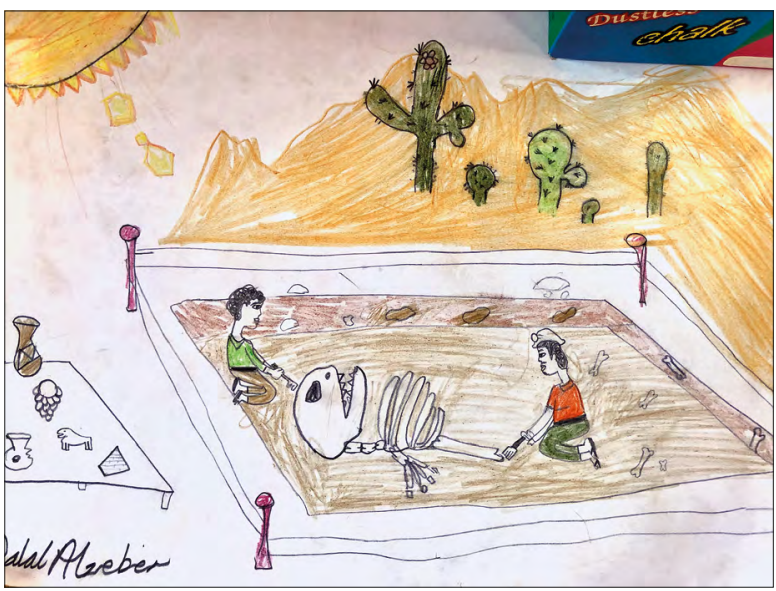

Fot. 10 Jak wyobrażają sobie pracę archeologa dzieci z Soby, Soba (2019)

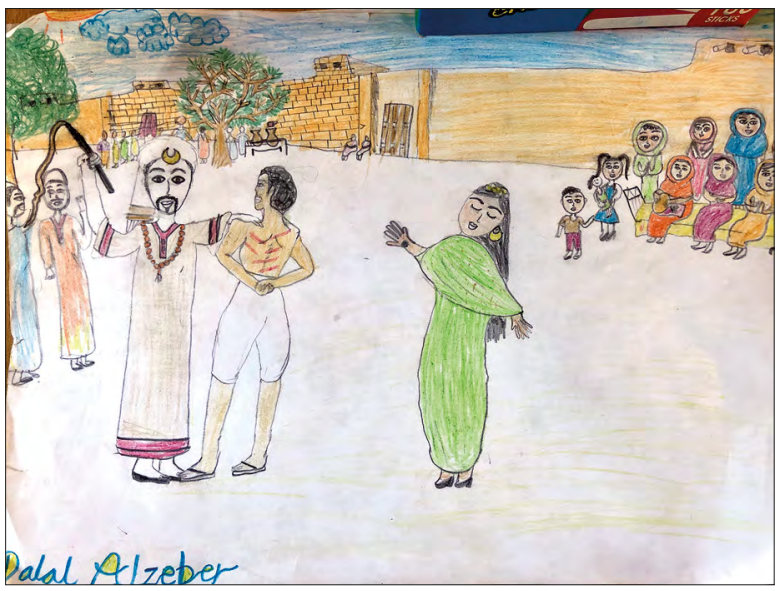

Fot. 11 Pocztówka przedstawiająca zwyczaj weselny Arabów Mugarba, Soba (2019)

do Polski i ofiarowane jednej z krakowskich szkół podstawowych (fot. 9). Plan ten został już zrealizowany. 25 kolorowych rysunków zostało przekazanych polskim dzieciom ze Społecznej Szkoły Podstawowej nr $4 \mathrm{im}$. J. Słowackiego w Krakowie. Polscy uczniowie odwzajemnili się tym samym. Kolorowe rysunki, w tym przypadku przedstawiające zabytki Krakowa, zabrane zostały do Sudanu. W kolejnym sezonie planowane jest zacieśnianie współpracy, tak na linii między obydwiema szkołami, jak i popularnonaukowej. Między innymi w czasie kolejnego sezonu badawczego chcielibyśmy zorganizować w Sudanie serię zajęć mających na celu popularyzowanie wiedzy o średniowiecznej Sobie.

Dotychczasowe kontakty ze szkołami w Soba skłaniają do następującej konkluzji. Po pierwsze, twierdzeniem graniczącym z truizmem jest, że szkoła pełni niezwykle ważną rolę w komunikacji ze społecznością lokalną, niwelując dystans między badaczami a okoliczną ludnością czy demityzując działalność terenową archeologów. Kontakty tego rodzaju stanowią także przepustkę do badań etnograficznych. Uczniowie mogą też pełnić rolę "odźwiernych” umożliwiających prowadzenie rozmów z dorosłymi członkami społeczności. Po drugie, wśród dzieci utrzymuje się duża wiedza na temat śladów archeologicznych. Przyzwyczajone są one do kontaktu z zabytkami archeologicznymi, takimi jak fragmenty ceramiki, narzędzia kamienne czy nawet ludzkie kości. Nie jest to dla nich temat tabu. Życie wśród zabytków jest częścią ich egzystencji. Podobnie jak w przypadku rozmów z dorosłymi, również dla dzieci opowieści o śladach archeologicznych są częścią historii każdej niemal rodziny. Najmłodsi wydają się także świadomi tego, co znajdować 
się może pod powierzchnią ziemi na zamieszkiwanym przez nich obszarze. Problem polega jednak na tym, iż nie są to dla nich przedmioty historycznie wartościowe. Są to co najwyżej ciekawe przedmioty. Wymiernym dowodem tego są wspomniane wyżej rysunki. Spośród 25 prac aż 17 przedstawia zabytki Meroe, Dżebel Barkal czy Al-Musawwarat as-Safra - miejsc kojarzonych ze starożytnymi królestwami Kusz i Meroe. Ani jeden rysunek nie przedstawia średniowiecznej Soby. Cztery rysunki odwołują się do obyczaju i religii; dwa do pracy archeologa (fot. 10, 11)

\section{Zakończenie}

Pierwszy sezon badawczy dostarczył informacji na temat stosunku mieszkańców Soby do śladów archeologicznych u progu nowej kampanii archeologicznej. To ważne m.in. ze względu na prawdopodobną zmianę postrzegania pozostałości historycznych, a także wpływ badań archeologicznych na procesy społeczne we współczesnej Sobie.

Zabytki są różnie traktowane, materializują pamięć, przemawiają w różnych dyskursach. Prawdopodobne jest, iż mogą także pełnić rolę swoistej broni w walce o zachowanie tożsamości, wartości kulturowych czy polityczną podmiotowość. Pierwszy sezon badań pokazał także, iż łączenie metody etnograficznej i wykopaliskowej może przynieść dobre rezultaty i to także tam, gdzie nie mamy do czynienia z ciągłością osadniczą, a tym samym i kulturową (kwestia pobudzenia refleksji nad dziedzictwem kulturowym). Kohabitacja ludzi ze śladami archeologicznymi kształtuje ich stosunek do zabytków, skłania do refleksji i zainteresowania historią oraz dziedzictwem kulturowym. Badania etnograficzne okazują się także niezwykle ważne dla współpracy z lokalną społecznością. Przypuszczenie, że miejscowa ludność posiada marne pojęcie o pracach wykopaliskowych i nie interesuje się historią, okazało się nie do końca prawdziwe. Konieczna jest jednak zmiana świadomości w zakresie pozytywnych konsekwencji prac wykopaliskowych, a także pobudzanie większego zainteresowania zabytkami, których prawowitymi depozytariuszami jest okoliczna ludność. Jednym z wątków, który bez wątpienia należałoby podjąć w przyszłości jest również kwestia społecznych solidarności, a mianowicie, czy w warunkach miejskich, a także w czasie kryzysu ekonomicznego i politycznego, w oparciu o ślady archeologiczne, może dochodzić do formowania się kolektywnych konceptów, praktyk czy narracji, wykorzystywanych do zmiany stylu życia, czy ekonomicznej i społecznej podmiotowości. 


\section{Bibliografia}

Appadurai, A. (1995). Playing with Modernity: The Decolonization of Indian Cricket. W: C.A. Breckenridge (red.), Consuming Modernity: Public Culture in a South Asian World (s. 23-48). Minneapolis, London: University of Minnesota Press.

Castañeda. E.Q. (2008). The „Ethnographic turn” in Archaeology. Research Positioning and Reflexivity in Ethnographic Archaeologists. W: E.Q. Castañeda, Ch.N. Matthews (red.), Ethnographic Archaeologies: Reflections on Stakeholders and Archaeological Practices (s. 25-61). Lanham: Altamira Press.

Drzewiecki, M., Ryndziewicz, R. (2019). Developing a New Approach to Research at Soba, the Capital of the Medieval Kingdom of Alwa, Archeologies: Journal of the World Archaeological Congress, 15, 314-337.

El Tayib, A. (1955). The Changing Customs of the Riverain Sudan. Sudan Notes and Records, 36 (2), 1-69.

Goody, J. (2012). Mit, rytuał, oralność (przeł. O. Kaczmarek). Warszawa: Wydawnictwo Uniwersytetu Warszawskiego.

Jakobielski, S. (1996). Nubia w Okresie Chrześcijańskim. W: M. Tymowski (red.), Historia Afryki do początku XIX w. (s. 545-568). Wrocław: Ossolineum.

Johnson, M. (2013). Teoria archeologii. Wprowadzenie (przeł. A. Tokarczuk-Różańska). Kraków: Wydawnictwo Uniwersytetu Jagiellońskiego.

Kurcz, M. (2007). Za trzecią kataraktą. Życie codzienne wsi północnosudańskiej. Kraków, Wrocław: Polskie Towarzystwo Ludoznawcze.

Kurcz, M. (2013). Sudan wyimaginowany - refleksje na temat kształtowania się pojęcia Sudan w okresie wpływów europejskich. Etnografia Polska, 57, 23-34

Mohammed, A.A., Welsby, D. (2011). Early States on the Nile. W: J. Ryle, J. Willis, S. Baldo, J. Madut (red.), The Sudan Handbook (s. 23-31). New York-London: James Currey.

Nora, P. (2009). Między pamięcią i historią. Les Lieux de Mémoire (przeł. P. Mościcki). Tytuł roboczy: Archiwum, 2, 4-12.

Obłuski, A. (2017). Alodia (Alwa). W: S. Aderinto (red.), African Kingdoms. An Encyclopedia.of Empires and Civilizations. Santa Barbara-Denver: ABC-CLIO, 15-16.

Salih, A.O.M. (1992). The Folklore of Archaeological Sites: A Case Study from Nawri in the Third Cataract Region. W: J. Sterner, N. David (red.), An African Commitment. Papers in honour of Peter Lewis Shinnie (s. 31-35). Calgary: University of Calgary Press.

Trimingham, S.J. (1965). Islam in the Sudan. London: Oxford University Press.

Yusuf F.H., (2005). The Arabs and the Sudan. From the Seventh to Early Sixteenth Century. Khartoum: SUDATek Limited. 


\section{Spis fotografii}

Fot. 1 Uczestnicy pierwszego sezonu wykopaliskowego, Soba (2019). Fot. M. Drzewiecki

Fot. 2 W czasie jednego z wywiadów z pasterzem wypasającym owce na stanowisku archeologicznym, Soba (2019). Fot. M. Kurcz.

Fot. 3 Stanowisko z lotu ptaka, Soba (2019). Fot. M. Drzewiecki

Fot. 4 Przedstawiciel zasiedziałej ludności Soby - Arabów Mugarba, Soba (2019). Fot. M. Kurcz.

Fot. 5 Kobieta ze społeczności Arabów Mugarba, Soba (2019). Fot. M. Kurcz.

Fot. 6 Serce średniowiecznej Soby z lotu ptaka (2019). Fot. M. Drzewiecki.

Fot. 7 Mężczyzna prezentuje rozcieracz pochodzący ze średniowiecznych ruin, Soba (2019). Fot. M. Kurcz.

Fot. 8 Mężczyzna ze swoim znaleziskiem, Soba (2019). Fot. M. Kurcz.

Fot. 9 Moment przekazania rysunków, Soba (2019). Fot. J. Ciesielska.

Fot. 10 Jak wyobrażają sobie pracę archeologa dzieci z Soby, Soba (2019). Fot. M. Kurcz.

Fot. 11 Pocztówka przedstawiająca zwyczaj weselny Arabów Mugarba, Soba (2019). Fot. M. Kurcz.

\section{Streszczenie}

Widoczne na powierzchni stanowiska archeologiczne pełniły zawsze ważną rolę w Sudanie. Będąc integralnymi częściami „mistycznej geografii”, były z reguły przestrzeniami ambiwalentnymi. Obdarzano je szacunkiem i ochroną. Wiele z nich łączyło się z tabu, magicznymi praktykami, stało się scenerią ludowych legend, opowieści o siłach nadprzyrodzonych czy ukrytych skarbach. Ich znaczenie w kulturze nigdy nie należało do niezmiennych, a każde z miejsc, w zależności od epoki historycznej, mogło wiązać się ze skrajnie różnymi interpretacjami. Dynamika postrzegania takich przestrzeni jest dziś szczególnie wyraźna na obszarach miejskich, gdzie na skutek przyspieszających procesów urbanizacyjnych każdy wolny kawałek ziemi jest na przysłowiową wagę złota. Z taką właśnie sytuacją mamy do czynienia w Soba -miejscu znanym w całym Sudanie z materialnych pozostałości po dawnej nubijskiej stolicy, a które dziś jest intensywnie rozwijającym się ośrodkiem podmiejskim aglomeracji chartumskiej. W artykule prezentuję wstępne wyniki badań etnograficznych nad stanowiskiem archeologicznym w Soba. W omówieniu przedstawiam także pierwsze rezultaty etnograficznych działań wśród lokalnych interesariuszy, które miały na celu zwiększenie zainteresowania miejscowej społeczności archeologią oraz dziedzictwem kulturowym. Realizowane etnograficzne badania są częścią archeologicznego projektu "Soba - the Heart of Kingdom of Alwa”.

Słowa klucze: stanowisko archeologiczne, ślady archeologiczne, badania etnograficzne, pamięć kulturowa, Soba, Sudan 


\section{Summary}

The visible archaeological sites were always important in Sudan. Being an integral part of the local "mystical geography", they were usually ambivalent but honoured and protected places. Many of those sites were linked with taboos and magical rites, or they gave rise to legends or beliefs in spirits and hidden treasures. However, the meaning of such spaces was never fixed and could be turned into completely different interpretation. This dynamic is particularly visible in urban centres, where because of rapid urbanization processes every empty piece of land is urgently needed. This is exactly what happens in Soba, long famous for the remains of the medieval capital of Nubia, today a rapidly developing suburban area of Khartoum. This presentation aims to discuss the very first findings of the research on the Soba archeological site from the ethnographic perspective. The paper represents an effort to understand the shifting interpretations of the Soba archaeological site, or, in other words, an attempt to answer how the meaning of this spot is differentiating in an urban setting. The ongoing ethnographic research is linked with the archaeological project "Soba - the Heart of Kingdom of Alwa".

Key words: archaeological site, archaeological traces, ethnographic research, cultural memory, Soba, Sudan 